Just ONE Click: The ReAlity OF INTERNET Retail Contracting

Ronald J. Mann \& Travis Siebeneicher 


\title{
Just ONE Click: The ReALITy OF INTERNET RETAIL CoNTRACTING
}

\author{
Ronald J. Mann \& Travis Siebeneicher ${ }^{*}$
}

\section{Introduction}

Scholars for decades have noted the possibility that standard-form contracts disadvantage consumers. ${ }^{1}$ For many years, that literature focused on the idea that sellers with market power draft contracts that are disadvantageous to consumers. ${ }^{2}$ Law and economics scholars, however, have been skeptical about that hypothesis, pointing out that a strategy of inefficient terms rarely would be the optimal technique for exploiting market power. $^{3}$ In recent years, however, the debate has shifted as new product distribution channels have changed the technology of contracting. Now, even firms without market

${ }^{*}$ Mann is a Professor of Law at the Columbia Law School. Siebeneicher is an associate at Fulbright \& Jaworski LLP and formerly was a fellow at the Center for Law, Business, and Economics, University of Texas School of Law. The authors are grateful for comments received at presentations of earlier versions of this project at the 2005 Annual Meeting of the Law and Society Association, at a faculty workshop at the University of Miami, for useful comments from Omri Ben-Shahar, Mary Rose, Elizabeth Warren, Jim White, and for statistical assistance from Alan Drury.

${ }^{1}$ E.g., Friedrich Kessler, Contracts of Adhesion - Some Thoughts About Freedom of Contract, 43 Colum. L. Rev. 629 (1943); Arthur Allen Leff, Contract as Thing, 19 AM. U. L. REV. 131 (1970); Stewart Macaulay, Private Legislation and the Duty to Read - Business Run by IBM Machine, the Law of Contracts and Credit Cards, 19 VAND. L. REV. 1051 (1966); Arthur Alan Leff, Unconscionability and the Crowd - Consumers and the Common Law Tradition, $31 \mathrm{U}$. PITT. L. REV. 349 (1970); Todd D. Rakoff, Contracts of Adhesion: An Essay in Reconstruction, 96 HARV. L. REV. 1174 (1983).

${ }^{2}$ E.g., Rakoff, supra note 1; Jeffrey Davis, Revamping Consumer-Credit Contract Law, 68 VA. L. REV. 1333 (1982).

${ }^{3}$ E.g., Alan Schwartz \& Louis L. Wilde, Imperfect Information in Markets for Contract Terms: The Examples of Warranties and Security Interests, 69 VA. L. REV. 1387 (1983); Lucian A. Bebchuk \& Richard A. Posner, One-Sided Contracts in Competitive Consumer Markets, 104 MiCH. L. REV. 827 (2006). 
power can exploit the cognitive failures of their customers through "shrouding" of terms and similar techniques. ${ }^{4}$

That concern has become more prominent with the rise of Internet retailing, where electronic standard-form contracts are used extensively, ${ }^{5}$ often undermining the notion of assent on which the contract paradigm traditionally depends. ${ }^{6}$ Scholars have worried that Internet retailers obscure one-sided terms so that customers will continue to shop at their sites, and do so more effectively than their brick-and-mortar counterparts. ${ }^{7}$ This, among other concerns, ${ }^{8}$ has led many to argue for a new contracting regime that deals with electronic contracting. ${ }^{9}$ Indeed, because software is often distributed online,

${ }^{4}$ See Xavier Gabaix \& David Laibson, Shrouded Attributes, Consumer Myopia, and Information Suppression in Competitive Markets, 121 QUARTERLY J. ECON. 505 (2006); Stefano Dellavigna \& Ulrike Malmendier, Contract Design and Self-Control: Theory and Evidence, 119 QUARTERLY J. ECON. 353 (2004).

${ }^{5}$ See Michelle E. Boardman, Contra Proferentem: The Allure of Ambiguous Boilerplate, 104 Mich. L. REV. 1105 (2006); Clayton P. Gillette, Rolling Contracts as an Agency Problem, 2004 WiS. L. REV. 679, 688 [hereinafter Gillette, Rolling Contracts]; Clayton P. Gillette, PreApproved Contracts for Internet Commerce, 42 Hous. L. REV. 975 (2005).

${ }^{6}$ E.g., Douglas G. Baird, Boilerplate and Market Power: The Boilerplate Puzzle, 104 MicH. L. REV. 933 (2006) (discussing problems with relying on assumption of arms-length negotiation); Gillette, Rolling Contracts, supra note 5, at 688; Ronald J. Mann, "Contracting” for Credit, 104 MiCH. L. REV. 899, 901-05 (2006) (describing problems with assent, readability, fragmentation, and the range of choice in standardized contracts); Robert A. Hillman \& Jeffrey J. Rachlinski, Standard-Form Contracting in the Electronic Age, 77 NYU L. REV. 429 (2002).

${ }^{7}$ See Stephen E. Friedman, Text and Circumstance: Warranty Disclaimers in a World of Rolling Contracts, 46 ARIZ. L. REV. 677 (2004); see also Sharon K. Sandeen, The Sense and Nonsense of Web Site Terms of Use Agreements, 26 HAMLINE L. REV. 499 (2003) (questioning the use of terms of use, introduced as part of the e-commerce industry).

${ }^{8}$ See David Gilo \& Ariel Porat, The Hidden Roles of Boilerplate and Standard-Form Contracts: Strategic Imposition of Transaction Costs, Segmentation of Consumers, and Anticompetitive Effects, 104 MICH. L. REV. 983 (2006) (discussing concerns about the strategic use of boilerplate to segment customers); Hillman \& Rachlinski, supra note 6, at 433 (addressing the arguments made by lawmakers and academics about adopting a new set of rules to deal with electronic contracts); Robert L. Oakley, Fairness in Electronic Contracting: Minimum Standards for Non-Negotiated Contracts, 42 HoUS. L. REV. 1041 (2005).

${ }^{9}$ See, e.g., Gillette, Rolling Contracts, supra note 5; Robert A Hillman, Boilerplate in Consumer Contract: Online Boilerplate: Would Mandatory Website Disclosure of E-Standard 
this is a major topic in the ALI's current project on Principles of the Law of Software Contracts. $^{10}$

Generally, that literature reflects an implicit syllogism: that aggressive contract drafting exploits consumer frailties and thus leads to higher profits for retailers. ${ }^{11}$ We reject that approach, offering in its place a new and simpler paradigm for understanding electronic contracting. Our central points are, first, that there is a substantial cost to making contracts enforceable and relatively little benefit to making them one-sided, and, second, that for most retailers the costs of making contracts enforceable exceed the benefits. To put it more directly, we suggest that retailers design Web sites balancing between the benefits of extracting purposeful assent and the burdens of complicating the purchase process. $^{12}$

We illustrate the paradigm with the results of a survey of the contracts of the 500 largest Internet retailers, showing that fewer than 10 percent of them have any enforceable contracts on their sites and that relatively few of the contracts include terms

Terms Backfire?, 104 MiCH. L. REV. 837 (2006); Oakley, supra note 8; Margaret Jane Radin, Humans, Computers, and Binding Commitments, 75 IND. L.J. 1125, 1126-27 (2000).

${ }^{10}$ See American LaW Institute, PrinciPles of the LAW OF SOFTWARE Contracts (Mar. 30, 2007 Discussion Draft) [hereinafter ALI PRINCIPLES].

11 The corollary is that merchants that fail to design contracts that exploit consumer frailties will be unable to compete with those that do, and thus will be driven from the market. See Oren Bar-Gill, Seduction by Plastic, 98 Nw. U. L. REV. 1373 (2004).

12 There is an extensive academic literature, relying heavily on "clickstream data," analyzing the strategies for designing Web site interfaces so as to maximize positive consumer response. E.g., Steven Bellman et al., Designing Marketplaces of the Artificial with Consumers in Mind: Four Approaches to Understanding Consumer Behavior in Electronic Environments, 20 J. INTERACTIVE MARKETING 21 (2006); Randolph E. Bucklin et al., Choice and the Internet: From Clickstream to Research Stream, 13 MARKETING LETTERS 245 (2002) (comparing Internet choice as captured by clickstream data to supermarket choice as captured by UPC scanner data); Alan L. Montgomery et al., Modeling Online Browsing and Path Analysis Using Clickstream Data, MARKETING SCIENCE (forthcoming) (using clickstream data to analyze the paths through Web sites that are more and less likely to result in purchases); Lan Xia D. Suharshan, Effects of Interruptions on Consumer Online Decision Processes, 12 J. CONSUMER PSYCH. 265 (2002). 
thought to be detrimental to consumers. ${ }^{13}$ Whatever the problems might be with those contracts and their enforcement (and there are some), the terms that the retailers select as worth the trouble of formal enforcement against their customers are relatively benign. ${ }^{14}$

Our discussion proceeds in three steps. We start with a discussion of two background topics: the role of documents in retail contracting and the legal framework for making Internet retail contracts enforceable. Second, we describe the empirical results, illustrating the rarity with which Internet retail contracts are enforceable or contain harsh terms. Third, we offer some statistical analyses to describe the small group of cases in which merchants do choose to obtain assent to their contracts.

\section{Background}

A brief preliminary discussion of the practical and legal context of retail contracting provides a useful backdrop for the data and analysis we present below.

${ }^{13}$ Florencia Marotta-Wurgler's papers on the interfaces used by firms that distribute software on the Internet also combine contracts and contracting interfaces with financial information about the drafters. See Florencia Marotta-Wurgler, Are 'Pay Now, Terms Later' Contracts Worse for Buyers? Evidence from Software License Agreements (NYU, Law and Economics Research Paper No. 05-10); Florencia Marotta-Wurgler, Competition and the Quality of Standard Form Contracts: An Empirical Analysis of Software License Agreements (NYU, Law and Economics Research Paper No. 05-11). Besides looking at a broader set of Internet merchants, our project has a different purpose. Rather than trying to assess whether pro-seller terms are associated with delayed presentation or competitive conditions, we try to explain why firms seek to obtain consent to their contracts.

14 The suggestion that the terms are "relatively" benign implies a baseline about the normal level of adverse terms in consumer contracts. We suggest that they are relatively benign primarily because our baseline expectation was that almost all of the contracts would include a large number of adverse terms. Whatever the reasons for the pattern here, it may not be unusual. Ted Eisenberg and Geoffrey Miller find a similar pattern in the terms of arbitration clauses in agreements among large publicly traded companies. See Theodore Eisenberg \& Geoffrey P. Miller, The Flight from Arbitration: An Empirical Study of Ex Ante Arbitration Clauses in Publicly-Held Companies’ Contracts (NYU, Law and Economics Research Paper No. 06-35). 


\section{A. The Practice of Retail Contracting}

Although consumer transactions pervade everyday life, the actual process of contracting remains largely unexamined. Generally, contractual obligation in the retail transaction has three possible sources. The first is the actions of the parties in conducting the transaction - the retailer's offering of a product at a particular price, the consumer's selection of the product, and the consummation of a sale. Under UCC Article 2, those actions, even in the absence of any documentation, will lead to a contract that incorporates the default terms of Article 2 to supplement the price and quantity terms that are likely to be clear from the overt actions of the parties. ${ }^{15}$

The second is any documents that the seller might provide the consumer to clarify the seller's obligations. In most retail contexts, those are likely to be quite simple, rarely extending beyond return policies, warranties, and the like. Although those documents are likely to be one-sided boilerplate drafted by the seller, the enforceability of those documents will rarely present important disputes, if only because they are likely to be limited to dickered terms, affirmative commitments by the seller (warranty and return provisions) or to disclaimers of warranties that UCC Article 2 specifically validates. ${ }^{16}$

The third likely source is a separate contract with a remote manufacturer that consumers are likely to see only when they have received the goods and opened the packaging. ${ }^{17}$ Although reasonable minds could differ on whether those so-called

${ }^{15}$ UCC § 2-204.

${ }^{16}$ E.g., UCC $\S \S 2-316$. The validation of warranties in the UCC is subject to the provisions of the Magnuson-Moss Warranty Act, 15 U.S.C. § 2301 et seq., that, generally speaking, invalidate implied warranties in cases in which merchants provide express warranties. For detailed discussion, see DANIEL J. KEATING, SALES: A SYSTEMS APPROACH ( $2^{\text {nd }}$ ed. 2003).

${ }^{17}$ For an in-depth discussion of contracts with delayed presentation of terms, see Robert A. Hillman, Rolling Contracts, 71 FORDHAM L. REV. 743 (2002). 
"shrink-wrap" contracts should be enforced, the law has coalesced around a general acceptance of their enforceability. ${ }^{18}$

The shift from brick-and-mortar retailer to online retailer does not necessarily change the potential sources of obligation. The customer's decision to place an item in a shopping cart and "click here to buy" provides the electronic parallel to the retail purchasing decision. The Web site often will have terms that govern its relationship with its customers. And manufacturers that distribute their products through Internet retailers are just as able to provide shrink-wrap terms in the box as they are when they distribute their products through catalog, mail-order, or conventional retail outlets. Our focus, as the introduction suggests, is on the second of those sources: the terms that the site will provide to govern its relationship with its own customers.

\section{B. Electronic Contracting}

With respect to traditional contract doctrine, the shift to an online contracting environment poses a more particular challenge. The statute of frauds traditionally required a writing to form a binding agreement involving a substantial sale of goods. ${ }^{19}$ Because interactions in an online contracting environment are by definition electronic, those rules required revision to permit online retailers the same ability to enter into binding arrangements with their customers that their brick-and-mortar predecessors enjoyed. To that end, the central provisions of the Uniform Electronic Transactions Act

${ }^{18}$ See Hillman, supra note 17, at 752-56 (discussing the different approaches that courts have taken in dealing with delayed presentation of terms); see also Hill v. Gateway 2000, Inc., 105 F.3d 1147 (7th Cir.), cert. denied, 522 U.S. 808 (1997); ProCD, Inc. v. Zeidenberg, 86 F.3d 1447 (7th Cir. 1996); Klocek v. Gateway, Inc. 104 F. Supp 2d 1332 (D. Kan. 2000). But see Arizona Retail Sys., Inc. v. Software Link, Inc., 831 F. Supp. 759 (D. Ariz. 1993); U.S. Surgical Corp. v. Orris, Inc., 5 F. Supp. 2d 1201 (D. Kan. 1998). For a forceful criticism of that analysis, see James J. White, Contracting Under Amended 2-207, 2004 WIS. L. REV. 723.

${ }^{19}$ See Old UCC § 2-201. 
(UETA) and of the Electronic Signatures in Global and National Commerce Act (ESIGN) require parity of treatment for electronic records and paper documents. ${ }^{20}$

Those statutes say nothing, however, about the ritual through which a retailer can ensure that it has obtained its customer's binding assent to a contract document. In the language of UETA, "[t]he effect of an electronic record $* * *$ is determined from the context and surrounding circumstances at the time of its creation, execution, or adoption.”21 In a face-to-face context, a concerned retailer will have little doubt that a formal signing of a contract document will be adequate evidence of assent to make the document binding against the consumer. In the online context, however, the youth of the Internet and continuing rapid development of typical user interfaces makes it much more difficult to be sure precisely what type of interface is reliably adequate.

On that point, the prudent retailer would turn to the growing body of case-law, which at this point provides considerable guidance as to what types of interfaces are and are not - sufficiently robust to obtain reliable assent from the retailer's customers. Although too simple in the real world (and thus for the empirical analysis that we present below), it is helpful to start by dividing Web site interfaces into two broad categories: click-wrap and browse-wrap. There are numerous variations of the two categories, and some conflicting decisions, but in general courts have been willing to uphold click-wrap interfaces and have been less receptive to browse-wrap interfaces.

\section{Click-wrap Cases}

For purposes of the statistical discussion in the parts that follow, we treat the term click-wrap as including the following types of interfaces: terms within a frame through

\footnotetext{
${ }^{20}$ UETA § 7; E-SIGN § 101, 15 U.S.C. § 7001.

${ }^{21}$ UETA $\S 9(\mathrm{~b})$.
} 
which a user must scroll to get to a radio button that must be checked to proceed; terms within a frame and a radio button outside and below that frame that must be checked to proceed; and a statement that the purchase is subject to terms and conditions, a link to those terms, and a radio button that must be checked to proceed. The first two forms of click-wrap have largely been accepted as forcing assent to all the terms included in the contract. ${ }^{22}$ The last category has also been held as giving the purchaser an "opportunity to review the terms . . . by clicking on the hyperlink" ${ }^{23}$; thus, these terms will likely govern a transaction preceded by such a click-wrap. There are some types of interfaces that courts have not yet addressed: sites with a pre-checked radio button and those with a radio button and a link to the terms that is browse-wrapped (i.e., not adjacent to the statement). Our expectation is that courts would treat those interfaces as adequate, on the theory that the consumer will have received adequate notice of the terms.

\section{Browse-wrap Cases}

There are numerous ways in which an interface could be treated as browse-wrap, but the most defining aspect of browse-wrap is that the user need take no affirmative action regarding the terms to complete the relevant transaction. So, for example, the term in its purest form includes an interface that presents a link at the bottom of the page to the terms and conditions. It also includes more ambiguous situations, as where there is a statement that the purchase is governed by terms and those terms are linked (but there is

${ }^{22}$ See ALI PRINCIPLES, supra note 10, § 2.01 \& Illustration 4 (codifying that rule); Juliet M. Moringiello \& William L. Reynolds, Survey of the Law of Cyberspace: Electronic Contracting Cases 2005-2006, 62 BUS. LAWY. 195, 201-03 (2006). Although discussing shrinkwrapped terms, the same analysis of ProCD has been applied to click-wrap agreements online. See 1-2 COMPUTER CONTRACTS § 2.05[2] (2005) ("The reasoning of ProCD, Inc. has been held to apply to click-wrap licenses.”).

${ }^{23}$ Treiber \& Staub, Inc. v. United Parcel Service, Inc., 474 F.3d 379 (7 $7^{\text {th }}$ Cir. 2007); DeJohn v. The TV Corp. Int’l, 245 F. Supp. 2d 913, 919 (N.D. Ill. 2003). 
no affirmative requirement that the user click a radio button acknowledging the terms).

There are numerous variations between those two extremes, but the one on which we have appellate judicial guidance is the initial end of the spectrum—-the pure browse-wrap.

The seminal browse-wrap case is Specht $v$. Netscape Communications Corp, ${ }^{24}$ where the court addressed whether browse-wrapped terms governed a transaction online. $^{25}$ The rule for enforcing terms in an online contract was clearly stated in the case: “[A] consumer clicking on a download button does not communicate assent to contractual terms if the offer did not make clear to the consumer that clicking on the download button would signify assent to those terms . . ..26 Although this rule was applied in the context of downloading software, ${ }^{27}$ it has been used as the test to determine whether certain terms are included in the sale of goods over the Internet. ${ }^{28}$ Thus, the test asks whether the site provides reasonable notice of the terms of the contract when making a purchase online. ${ }^{29}$ The Specht court went on to find that a reasonably prudent Internet user would not necessarily scroll down to see the bottom of the page. ${ }^{30}$ Thus, Specht provides relatively clear guidance that browse-wrap agreements (or links to such an agreement) that a consumer cannot see on the screen do not force assent.

${ }^{24}$ Specht v. Netscape Comm’ns Corp., 306 F.3d 17 (2d Cir. 2002).

${ }^{25}$ Id. at 20 (determining whether the plaintiff "agreed to be bound by the software license terms ... even though plaintiffs could not have learned of the existence of those terms unless ... they had scrolled down the webpage to a screen located below").

${ }^{26}$ Id. at $29-30$.

${ }^{27}$ Id. at 20-21 (discussing the facts of the case-users downloading software provided online).

${ }^{28}$ See, e.g., Defontes v. Dell Computers Corp., 2004 R.I. Super. LEXIS 32, *17 (2004) (applying the Specht rule to the sale of computers over the Internet).

${ }^{29}$ Specht, 306 F.3d at 32 ("We are not persuaded that a reasonable prudent offeree in these circumstances would have known of the existence of license terms.”).

${ }^{30} \mathrm{Id}$. (holding that "a reference to the existence of license terms on a submerged screen is not sufficient to place consumers on inquiry or constructive notice of those terms.”). 
As Mark Lemley and others have noted, the distinction between clickwrap and browsewrap has blurred in recent years, as lower courts have suggested the possibility that browse-wrap might be enforceable in some contexts. ${ }^{31}$ Register.com, Inc. v. Verio, Inc. is a typical example. The plaintiff in that case tried to use Specht as a way to get around the terms of which it had knowledge. ${ }^{32}$ The plaintiff argued that like the terms in Specht, the terms were only included as browse-wrap, with no forced assent or notice, because the terms only appeared when a query (the equivalent of making a purchase from the defendant) was submitted. ${ }^{33}$ The court rejected plaintiff's argument because plaintiff had made numerous queries, which had the effect of putting plaintiff on notice of the terms of making queries, such that later purchases would be subject to those terms. ${ }^{34}$ This presents the first exception to the rule stated in Specht-a contract can be enforceable even if there is not reasonable notice: "when a benefit is offered subject to stated conditions and the offeree makes a decision to take the benefit with knowledge of the terms of the offer, the taking constitutes an acceptance of the terms.”35

As the discussion of Register.com suggests, the lower court cases do not to date provide any reliable template for designing an enforceable browse-wrap interface. At most, those cases suggest that Web site terms can bind a visitor when circumstances suggest that the visitor should have been aware of the terms, typically because of

${ }^{31}$ See Mark A. Lemley, Terms of Use, 91 MinN. L. REV. 459 (2006); ALI PRINCIPLES, supra note 10, § 2.01 comment b (discussing Ticketmaster Corp. v. Tickets.com, Inc., 2003 WL 21406289 (C.D. Cal. 2003)); Moringiello \& Reynolds, supra note 22, at 201-03.

32356 F.3d 393, 401 (2004) (plaintiff arguing that it did not receive "legally enforceable notice of the conditions Register [the defendant] intended to impose”).

${ }^{33} I d$.

${ }^{34}$ Id. at 403.

${ }^{35}$ Register.com, 356 F.3d at 403. 
repeated use of the site. ${ }^{36}$ This theory seems particularly attractive in cases that involve screen scraping, where it is fair to say that the visitor knows that the activity is unauthorized. ${ }^{37}$ It is harder to see how that theory would apply to consumer transactions involving a retail site, where the visitor might use the site dozens of times without ever noticing the terms of use. ${ }^{38}$

In theory at least, a lawyer might decide to "take a chance" on the enforceability of a browse-wrap interface, particularly one of the better forms - such as one with a preclicked radio button. But the central point for our purposes is clear. A well-advised Web site designer trying to design an interface that reliably would produce a binding contract would require some affirmative action from the user to indicate assent to the document in question. As the draft ALI Principles suggest, a fair assessment of the cases is that a click-through interface is a "safe harbor" of enforceability beyond which Web sites stray at their own peril. ${ }^{39}$ We now turn to our data to consider the extent to which that problem motivates retailers as they design their sites.

\section{The Reality of Internet Retail Contracting}

Determining what businesses do is not a science; determining what e-commerce businesses do is less than that. E-commerce businesses are continually changing as both

${ }^{36}$ The ALI Principles state: "[B]rowsewrap may be acceptable, according to some courts, when the transferee should have knowledge of the standard form from previous visits to a site or based on reasonable notice.” See ALI PRINCIPLES, supra note 10, § 2.1 comment b. The idea that the "knowability" of terms might be adequate to make them enforceable is particularly important in the realm of open source licenses, where the knowability of the terms of a license like the General Public License often will be the principal basis for treating it as a binding contract.

${ }^{37}$ See Lemley, supra note 31, at 472-76; Ticketmaster Corp. v. Tickets.com, 2003 U.S. Dist. LEXIS 6483 (C.D. Cal. 2003), slip op. at *8-*10.

${ }^{38}$ Lemley, supra note 31, at 476-77.

${ }^{39}$ See ALI PRINCIPLES, supra note 10, § 2.1 comment c. 
the technology and market change. Defining one class of online sellers is elusive when Web sites come and go, businesses offer new and discontinue old products, and companies merge (both entities and online presences). The approach we have adopted here is to take a static picture of a class of online retailers and draw a dataset from that class. ${ }^{40}$ The dataset consists of the top five hundred Internet retailers, determined by Internet Retailer as of $2005,{ }^{41}$ together with information about the contracts that those retailers use.

Part A explains the dataset. The point was to collect three categories of information about Internet retail contracting: facts about the businesses and their sites, the terms of the contracts that they use, and the robustness of assent required by the interface at their Web site. Part B introduces the study by describing the businesses in our dataset, which present an unusually broad cross-section of retailers of various sizes and trade lines. Finally, Part C presents our two main findings: how rarely retailers have designed an interface to obtain assent to their posted terms, and the rarity with which the posted terms include harsh pro-retailer terms.

\section{A. Dataset}

Our primary goal is to examine the relation between a retailer's business model and its contracting practices. Thus, our analysis generally combines survey data about the businesses and their Web sites collected and published by Internet Retailer, with two types of information about contracts that we have collected and coded by hand: the terms of the contracts themselves, together with information about the contracting interfaces at

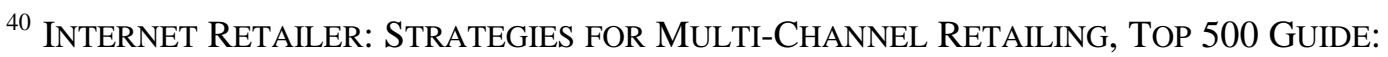
PROFILES AND STATISTICS OF AMERICA's 500 LARgEST RETAIL WEB Sites RANKed By ANNUAL SALE (2006) [hereinafter I500].

${ }^{41}$ I500, supra note 40, at 6-18. 
the retailer's site. The resulting dataset offers a unique opportunity to examine contracting practices, because it includes a cross-section of contracting terms and practices across numerous sectors, together with uniform business information about those firms.

\section{Business Information}

The information collected from Internet Retailer falls into three general categories. First, as evidence of the general size and scope of the business and its site, we have the business's 2005 Web sales (in dollars), the number of monthly visits to the Web site, and the number of monthly unique visitors.

Second, as evidence of market power, we calculated the business's market share within its principal merchandising market from Internet Retailer and then used that information to calculate CR4 and Herfindahl-Hirschman indices (HHI) for each of the 14 principal merchandising markets into which Internet Retailer divides the dataset. ${ }^{42}$

Finally, we have a group of miscellaneous data points that relate to the business models of the firms and the size of their Web sites: conversion rate (the percentage of shoppers that completed purchases), average ticket (in \$), total SKUs on the Web site, the principal merchandising market (allocating the businesses into 14 categories), and merchandising channel (which divides firms among consumer-branded manufacturers, catalog/call center, retail chain, and virtual store).

${ }^{42}$ We calculated CR4 as the percentage share that the top four firms in each market held of the total sales of all firms in each market. We calculated the HHI as the sum of the squares of the percentage shares of all firms in each market. 


\section{Contracting Terms and Interfaces}

To get information about the contracting terms and interfaces of those retailers, we collected data from all of the sites during the first quarter of 2006. Specifically, we logged onto each retailer's home page, ${ }^{43}$ selected a product to purchase, and began the purchase process. Where necessary, we registered at the site. ${ }^{44}$ We continued through the purchase process to the point where we were reasonably sure that we had completed an order. We saved screen shots of the home page and of each page that indicated a statement relating to consent of terms. ${ }^{45}$

During the process, we also collected copies of all contract documents visible from pages that were visited during the purchase process. Looking broadly for relevant documents, we collected not only "terms and conditions", but also "FAQs" and return and privacy policies and disclaimers. Ultimately, we collected more than 1200 documents from 500 sites.

After collecting the information, we coded it to extract two types of information for each site. First, we made a determination related to the level of assent required, ordering assent along an eight-point continuum drawn from the cases discussed above, as

${ }^{43}$ If the home page was a page directing the user to multiple companies-a parent company directing the user to its subsidiaries - one subsidiary was selected and we determined both the terms and the type of assent from that one site. See, e.g., Federated Department Stores, I500 Dataset.

${ }^{44}$ If the sites required registration, we collected screen shots of the registration process and all terms and conditions and statements of consent.

${ }^{45}$ We did not collect screen shots of picking a product and of the product in a virtual cart that included neither terms nor consent interfaces. 
modified to reflect the actual practices on the sites. ${ }^{46}$ The eight points of our continuum are as follows:

\begin{tabular}{|l|l|}
\hline 1 & $\begin{array}{l}\text { Pure browse-wrap, with no language on any of the order pages } \\
\text { that suggests agreement. }\end{array}$ \\
\hline 2 & $\begin{array}{l}\text { Statement that a transaction involves consent to a document that } \\
\text { is not displayed. }\end{array}$ \\
\hline 3 & $\begin{array}{l}\text { Statement that a transaction involves consent to a document that } \\
\text { is linked. }\end{array}$ \\
\hline 4 & $\begin{array}{l}\text { Statement immediately adjacent to "place order" button that } \\
\text { transaction involves consent to a specified, linked document. }\end{array}$ \\
\hline 5 & Pre-checked radio button. \\
\hline 7 & Radio button that must be affirmatively checked. \\
\hline 8 & $\begin{array}{l}\text { Scrolling required, with radio button. } \\
\text { Documents pushed to user at time of entering site or when } \\
\text { registering, with registration being a condition to entering order } \\
\text { placement process. }\end{array}$ \\
\hline
\end{tabular}

Second, we reviewed the documents at the site. A typical contract - the most representative terminology styles it "Terms of Use" - contains provisions that address site usage (regulation of online conduct, scope of license, proprietary rights in content, third party proprietary rights, security, privacy and disclaimers), provisions that address purchases (return policies, warranties, limitations of liability and disclaimers), and provisions that relate to modification or enforcement of contract terms (choice of law, choice of forum, and the like). Our review focused on the use of contracting terms that modify the default rules of UCC Article 2 (or the Restatement, as the case may be) in ways that appear to favor sellers. We selected clauses based on their prominence either

${ }^{46}$ For each site, we based the determination of consent level on the document with the highest consent level. 
in the literature about boilerplate or frequent appearance in the contracts that we reviewed. For lack of a better term, we refer to these as "pro-seller" clauses. The nine terms for which we collected data were as follows:

- $\quad$ Disclaimer of implied warranties

- $\quad$ Limitation of the types of liability (typically consequential damages)

- Limitation of the amount of liability (damage caps, typically at the purchase price)

- $\quad$ Choice of law

- $\quad$ Choice of forum (court)

- $\quad$ Choice of forum (arbitration)

- $\quad$ Class action waiver

- Jury trial waiver

- $\quad$ Contractual statute of limitations

B. Describing the I500 Retailers

A preliminary description of our business variables is valuable for several reasons. First, they give a sense of the broad variety of firms involved in Internet retailing - among what sectors is it distributed, how big are the retailers, what is the variation in size, and the like. More importantly, they provide the context for understanding the findings we discuss below about the relatively benign terms and interfaces that these businesses use. Table 1 provides a summary description of our data about the retailers. 
TABLE 1 (SUMMARY OF BUSINESS VARIABLES)

\begin{tabular}{||c|c|c|c|c|c|c||}
\hline \hline & $\begin{array}{c}\text { WEBSALES } \\
(\$ \mathrm{M})\end{array}$ & $\begin{array}{c}\text { MONTHLY } \\
\text { VISITS (M) }\end{array}$ & $\begin{array}{c}\text { MONTHLY } \\
\text { UNIQUE } \\
\text { VISITORS } \\
(\mathrm{M})\end{array}$ & $\begin{array}{c}\text { CONVERSION } \\
\text { RATE (\%) }\end{array}$ & $\begin{array}{c}\text { AVERAGE } \\
\text { TICKET } \\
(\$)\end{array}$ & $\begin{array}{c}\text { TOTAL } \\
\text { SKUS } \\
(\mathrm{K})\end{array}$ \\
\hline Mean & 138 & 2.8 & 1.5 & 3.46 & 170 & 927 \\
\hline Median & 22 & 0.79 & 0.50 & 2.5 & 100 & 11,000 \\
\hline S.D. & 540 & 7.9 & 3.3 & 3.5 & 260 & 6,200 \\
\hline Skewness & 9.8 & 8.7 & 6.7 & 3.7 & 8.1 & 9.9 \\
\hline IQR $^{47}$ & 51 & 1.7 & 1.1 & 2.1 & 90 & 56 \\
\hline $\mathrm{N}$ & 500 & 500 & 475 & 490 & 492 & 311 \\
\hline
\end{tabular}

Because our data start with the largest retailers and include all retailers in the top 500 , it should be no surprise that on most of the financial variables, our data are highly skewed, with a substantial drop-off in size from the largest to smallest retailers in our dataset. Using Web sales, for example, the largest (Amazon.com) has annual sales of more than $\$ 8$ billion dollars, while the smallest retailer in our dataset (Emitations.com) has sales of only $\$ 3.2$ million. Indeed, in most cases there is a striking drop-off after a small handful of very prominent retailers. Table 2 shows the five largest sites for each of the variables reported in Table 1. percentile.

${ }^{47}$ The IQR is the inter-quartile ratio - the share of the firms between the $25^{\text {th }}$ and $75^{\text {th }}$ 
TABLE 2 (TOP RETAILERS ON BUSINESS VARIABLES)

\begin{tabular}{|c|c|c|c|c|c|c|}
\hline & $\begin{array}{l}\text { WEBSALES } \\
(\$ \mathrm{M})\end{array}$ & $\begin{array}{l}\text { MONTHLY } \\
\text { VISITS (M) }\end{array}$ & $\begin{array}{l}\text { MONTHLY } \\
\text { UNIQUE } \\
\text { VISITORS } \\
(\mathrm{M})\end{array}$ & $\begin{array}{c}\text { CONVERSION } \\
\text { RATE (\%) }\end{array}$ & $\begin{array}{l}\text { AVERAGE } \\
\text { TICKET (\$) }\end{array}$ & $\begin{array}{l}\text { TOTAL SKUS } \\
(\mathrm{M})\end{array}$ \\
\hline 1 & $\begin{array}{c}8,500 \\
\text { (Amazon) }\end{array}$ & $\begin{array}{c}120 \\
\text { (Amazon) }\end{array}$ & $\begin{array}{c}43 \\
\text { (Amazon) }\end{array}$ & 31 (Peapod) & $\begin{array}{c}4,000 \\
\text { (BMI } \\
\text { Gaming) }\end{array}$ & 80 (Abebooks) \\
\hline 2 & $\begin{array}{l}3,800 \\
\text { (Office } \\
\text { Depot) }\end{array}$ & 63 (Apple) & $\begin{array}{l}24 \text { (Wal- } \\
\text { Mart) }\end{array}$ & $\begin{array}{c}29 \\
\text { (FreshDirect) }\end{array}$ & $\begin{array}{c}1,600 \\
\text { (IBuy- } \\
\text { Digital.com) }\end{array}$ & 60 (Alibris) \\
\hline 3 & $\begin{array}{c}3,800 \\
\text { (Staples) }\end{array}$ & $\begin{array}{l}42 \text { (Wal- } \\
\text { Mart) }\end{array}$ & 21 (Disney) & $\begin{array}{l}24 \text { (Market } \\
\text { Day) }\end{array}$ & $\begin{array}{c}1,500 \\
\text { (iFloor.com) }\end{array}$ & 30 (Biblio) \\
\hline 4 & 3,780 (Dell) & 42 (Target) & 19 (Apple) & 23 (Magellan’s) & $\begin{array}{c}1,500 \\
\text { (Skynet) }\end{array}$ & $\begin{array}{c}22 \\
\text { (CafePress.com) }\end{array}$ \\
\hline 5 & 2,830 (HP) & $\begin{array}{l}39 \text { (Over- } \\
\text { stock.com) }\end{array}$ & 18 (Sears) & 20 (NBTY) & $\begin{array}{c}1400 \\
\text { (Smooth- } \\
\text { Fitness.com) }\end{array}$ & $\begin{array}{c}20 \text { (1-800- } \\
\text { Contacts) }\end{array}$ \\
\hline
\end{tabular}

In addition to the quantitative data about each firm and its Web site, Internet Retailer also broke the firms down along two separate dimensions related to the type of business. First, Internet Retailer divides all of the retailers into fourteen separate categories based on the retailer's product market, as detailed in Table 3. Those data are useful because they permit us to explore the possibility that contracting practices might differ based on the type of product the retailer sells. Second, Internet Retailer divides the merchants into four separate "merchandising channels" based on the relation between the Web site and the retailer's offline operations. Generally, they run on a spectrum from virtual (no brick-and-mortar operations, like Amazon.com) to catalog/call center (such as LLBean) to branded manufacturer (such as Dell) to retail chain (such as Office Depot). Table 4 summarizes the breakdown of merchants by merchandising channel. 
TABle 3 (Product Markets of I400 Retailers)

\begin{tabular}{||c|c|c|c|c|c|c||}
\hline MARKET & $\begin{array}{c}\text { VOLUME } \\
(\text { M\$) }\end{array}$ & $\%$ & N & $\begin{array}{c}\text { M\$/STORE } \\
\text { (RANK) }\end{array}$ & $\begin{array}{c}\text { CR4 } \\
(\%)\end{array}$ & HHI \\
\hline $\begin{array}{c}\text { Mass Merchant/Dep't } \\
\text { Store }\end{array}$ & 18,300 & 27 & 27 & $678(2)$ & 72 & 2570 \\
\hline Computers/Electronics $^{48}$ & 17,700 & 26 & 54 & $328(3)$ & 64 & 1270 \\
\hline Office Supplies & 10,300 & 15 & 11 & $936(1)$ & 99 & 4550 \\
\hline Apparel/Accessories & 7,060 & 10 & 109 & $65(8)$ & 28 & 350 \\
\hline Books/CDs/DVDs & 2,500 & 3.6 & 29 & $86(5)$ & 74 & 1740 \\
\hline Housewares/Furnishings & 2,410 & 3.5 & 55 & $44(9)$ & 50 & 1010 \\
\hline Specialty/Non-Apparel & 2,330 & 3.4 & 60 & $39(13)$ & 34 & 470 \\
\hline Food/Drug & 1,879 & 2.7 & 26 & $72(6)$ & 57 & 1190 \\
\hline Health/Beauty & 1,750 & 2.5 & 17 & $103(4)$ & 90 & 3420 \\
\hline Sporting Goods & 1,340 & 1.9 & 39 & $36(14)$ & 52 & 860 \\
\hline Flowers/Gifts & 1,200 & 1.7 & 18 & $67(7)$ & 75 & 1870 \\
\hline Hardware/Home Impr. & 851 & 1.2 & 22 & $39(11)$ & 87 & 2230 \\
\hline Toys/Hobbies & 741 & 1.1 & 19 & $39(12)$ & 77 & 3630 \\
\hline Jewelry & 615 & 0.9 & 14 & $43(10)$ & 73 & 2070 \\
\hline TOTAL & $\mathbf{6 8 , 9 0 0}$ & $\mathbf{1 0 0}$ & $\mathbf{5 0 0}$ & $\mathbf{1 3 8}$ & -- & -- \\
\hline
\end{tabular}

TABle 4 (Merchandising ChanNels of I400 Retailers)

\begin{tabular}{||c|c|c|c|c||}
\hline \hline CATEGORY & VOLUME (B\$) & $\%$ & N & $\begin{array}{c}\text { M\$/STORE } \\
\text { (RANK) }\end{array}$ \\
\hline Retail Chain & 27.8 & 40 & 143 & $194(2)$ \\
\hline Virtual & 20.8 & 30 & 225 & $92(3)$ \\
\hline $\begin{array}{c}\text { Branded } \\
\text { Manufacturer }\end{array}$ & 10.5 & 15 & 45 & $233(1)$ \\
\hline $\begin{array}{c}\text { Catalog/Call } \\
\text { Center }\end{array}$ & 9.85 & 14 & 87 & $11(4)$ \\
\hline TOTAL & 68.9 & 100 & 400 & 138 \\
\hline
\end{tabular}

\section{The Rarity of Binding Interfaces or Pro-Seller Contracts}

Because our principal goal is to explore the contracting practices of Internet retailers, the business variables discussed above are important primarily as background.

${ }^{48}$ If it seems odd that Table 2 reports Amazon.com as the largest merchant with more than $\$ 8$ billion in sales and Table 3 reports total sales for the book/CD/DVD sector of only $\$ 2$ billion, this is because Internet Retailer codes Amazon.com as a mass merchant/department store. See infra note 57 (discussing categories of sales by Amazon.com). 
Turning to the contracting data, we confess surprise at what we found in both the interfaces and in the contracts themselves.

On the first point, our preliminary hypothesis, bolstered by casual experience purchasing on the Internet, was that the desire of Internet retailers to maintain high conversion rates would motivate many retailers to design interfaces that did not obtain a robust "click-through" assent from their customers. Still, skeptical as we were before our data collection, we were startled to find that barely 10\% (61 of 500) of our dataset extract any form of consent beyond pure browse-wrap. Indeed, dividing the dataset at the point that seems to us most likely to reflect the broadest reasonable estimate of legal enforceability (the point at which the retailer presents a pre-checked radio button to reflect assent), less than 6\% (28 of 500) of the retailers have enforceable contracts on their Web sites. ${ }^{49}$ Table 5 summarizes the data on that point.

TABLE 5 (Distribution OF ASSENT)

\begin{tabular}{||c|c|c||}
\hline FORM OF ASSENT & $\mathrm{N}$ & $\%$ \\
\hline Pure browse-wrap & 439 & 88 \\
\hline Reference to document & 9 & 1.8 \\
\hline $\begin{array}{c}\text { Reference to linked } \\
\text { document }\end{array}$ & 6 & 1.2 \\
\hline $\begin{array}{c}\text { Reference to linked } \\
\text { document beside "order" } \\
\text { button }\end{array}$ & 18 & 3.6 \\
\hline Pre-checked radio button & 3 & 0.6 \\
\hline Unchecked radio button & 15 & 3.0 \\
\hline Scrolling to radio button & 6 & 1.2 \\
\hline Registration & 4 & 0.8 \\
\hline TOTAL & 500 & 100 \\
\hline
\end{tabular}

${ }^{49}$ Although we have not comprehensively examined the interfaces of non-U.S. retailers, it is interesting that major sites like Amazon.com and Dell.com have substantially different terms at their non-U.S. Web sites, but quite similar interfaces. 
The data about the terms of the contracts are even less consistent with our prior expectations. Our working hypothesis was that the rarity with which consumers read contracts presented to them on the Internet makes it almost costless for a retailer to include pro-seller terms in any contract that the retailer drafts. Thus, we expected, retailers would almost always include the kinds of "pro-seller" terms that are standard for boilerplate contracts with consumers in other contexts. We were surprised to find that none of the nine clauses that we collected appeared in more than half of the contracts. Perhaps the most surprising finding is that arbitration clauses appear in less than a tenth of the contracts (only 44 of 500 retailers). ${ }^{50}$ The failure of half of the sites to include clauses disclaiming consequential damages and implied warranties ${ }^{51}$ is also surprising, given the ever-present possibility that customers would sue an Internet retailer seeking to recover damages either from a data breach at the site or from harms to their personal computer arising out of interaction at the site. ${ }^{52}$

${ }^{50}$ This is particularly surprising given the likelihood that arbitration will be the only costeffective method of resolving small-dollar disputes between Internet merchants and their customers. See, e.g., Sayeedi v. Walser, Civ. Ct. New York, No. 10610/06 (Feb. 27, 2007) (dismissing action by disgruntled eBay purchaser for want of personal jurisdiction over eBay merchant) (discussed in Fass, Contact Held Insufficient to Sue eBay Seller, N.Y.L.J., Mar. 7, 2007). It also warrants comparison to the credit card context, where arbitration agreements are standard for disputes that are much larger in size, and apparently often have the effect of insulating the card issuer from judicial review of its actions. See Mann, supra note 6.

${ }^{51}$ With respect to implied warranties, one possible explanation is that many of the sites provide express warranties, and thus that any disclaimer would violate the Magnuson-Moss Warranty Act, 15 U.S.C. § 2308(a).

${ }^{52}$ For comparative purposes, I note that such clauses are ubiquitous in contracts with credit card issuers, where the issuers' need for such clauses is considerably less clear. 
TAble 6 (Frequency of Pro-Seller Terms)

\begin{tabular}{||c|c|c||}
\hline CLAUSE & $\mathrm{N}$ & $\%$ \\
\hline $\begin{array}{c}\text { Disclaimer of Implied } \\
\text { Warranties }\end{array}$ & 245 & 49 \\
\hline $\begin{array}{c}\text { Limitation of Damage } \\
\text { Types }\end{array}$ & 243 & 49 \\
\hline Choice of Law & 201 & 40 \\
\hline Choice of Forum & 159 & 32 \\
\hline $\begin{array}{c}\text { Limitation of Damages } \\
\text { (Caps) }\end{array}$ & 108 & 22 \\
\hline Arbitration & 44 & 7 \\
\hline Class Action Waiver & 33 & 6 \\
\hline $\begin{array}{c}\text { Contractual Statute of } \\
\text { Limitations }\end{array}$ & 28 & 1 \\
\hline Jury Trial Waiver & 6 & 9 \\
\hline
\end{tabular}

In some ways, the data we present here speak with clarity. Most obviously, they seem to us to go far toward resolving the concerns that have preoccupied other writers: that Internet retailers are taking advantage of the electronic interfaces the Web permits to bind their customers to pro-seller contracts. The fact is, at least for now, at least at the largest retailers, the contract terms and contracting interfaces of Internet retailers are surprisingly benign.

To return to the framework we suggest in the Introduction, retailers should extract consent to pro-seller terms whenever the costs of an additionally complex interface are less than the benefits of the more favorable terms. Thus, to make sense of the data we must infer some combination of relatively high costs of extracting consent and relatively low benefits of pro-seller contracts. More directly, if retailers act rationally, the costs of the additional click must be substantial or many more retailers would be making their contracts more favorable to themselves. The converse proposition is more intriguing to the student of commercial transactions: the benefits of these terms must be surprisingly 
slight or they would overcome the costs of interface design much more often than they do. ${ }^{53}$

There is, to be sure, another side to the phenomenon. Considering the findings together it is natural to ask, for example, why a business would bother to write a proseller contract if it is not going to make the contract enforceable against its customers. It reaps the bad publicity of having a harsh attitude toward its customers but gains none of the benefits of protection from legal liability. We speculate that much of the answer is that the benefits of enforceable contracts are relatively slight because many customers will abide by the terms of contracts even if they are not enforceable. In part this might be caused by a tendency to treat the terms of agreements as reference points for fair resolution of disputes, wholly apart from the anticipated outcomes of litigation. ${ }^{54}$ It also might reflect the disparity in sophistication between the retailer and the customer - so that a customer might readily abandon a dispute when confronted by the retailer with terms from the Web site that purport to undermine the ability to pursue the claim through litigation.

If this analysis is correct, the mere possibility of disgruntled customers is not enough to justify the extra click that brings enforceability; the Internet retailer must have a concern that a substantial number of the disgruntled customers will ignore the terms of

${ }^{53}$ Retailers without click-through interfaces still might assume that their terms will be enforceable. As discussed above, they might be relying on recent cases suggesting that they would have at least a chance of enforcing browse-wrap terms against their customers. Our point, however, is that the transactional lawyer designing the Web site would use a click-through interface to ensure enforceability if the value of enforceability was substantial in relation to the cost of the additional click.

${ }^{54}$ See Oliver Hart \& John Moore, Contracts as Reference Points (Harvard Law School, Olin Center for Law, Economics, and Business, Discussion Paper No. 572) (December 2006 draft). 
sale posted on the Web site and pursue litigation. Absent that concern, there is little basis for making the contract binding, though there is some basis for having the contract include terms that limit the rights of the customer. At the same time, to the extent the purpose of the contract is to palliate disgruntled customers, there is good reason for the contract to be written in terms that will sound reasonable to the typical consumer, which suggests that retailers should include pro-seller clauses only in cases where they are likely to be useful in the event of disputes.

This dynamic is clearest in the context of privacy policies. The retailer gains little or nothing from making a privacy policy binding, because the typical privacy policy consists solely of representations and commitments by the retailer as to the collection, use and protection of information. If the document includes no commitments on the part of the customer, the only significance of making the document a binding contract is that it allows customers to sue the retailer for breach of contract. Surprisingly enough, there is some authority for the proposition that a retailer is not subject to suit by its customers even if it does violate the terms of its privacy policy. ${ }^{55}$ Thus, in this context, the principal source of exposure for violating a privacy policy is a complaint from the Federal Trade Commission enforcing Section 5 of the FTC Act. ${ }^{56}$ Similarly, here we might expect that enforcement by the Federal Trade Commission eventually might become one of the principal methods of holding Internet retailers to the terms they offer on their Web sites.

${ }^{55}$ E.g., Northwest Airlines Privacy Litigation, 2004 WL 1278459 (D. Minn.); In re Jet Blue Airways Corp. Privacy Litigation, 379 F. Supp. 2d 299 (E.D.N.Y. 2005).

${ }^{56}$ See Federal Trade Commission, Enforcing Privacy Promises: Section 5 of the FTC Act, www.ftc.gov/privacy/privacyinitiatives/promises.html. 


\section{Explaining the Puzzle of Internet Contracting}

Part III explains why businesses rarely would make contracts binding, and why they often though not always would include pro-seller terms in their contracts. It does not, however, try to explain which businesses will make their contracts binding or include pro-seller terms. We close with some preliminary analyses of those questions, attempting to understand what distinguishes the retailers that do draft pro-seller contracts or obtain consent to their contracts from those that do not. Our working hypothesis when we began the project was that the best place to look for an explanation of variation in contracting practices was the characteristics of the businesses in question. To explain, consider Dell and Amazon as the two paradigm retailers at opposite ends of a spectrum of contracting needs. Dell has a clear need for a contract with robust assent. Dell's products are complicated electronic devices that even for the best of manufacturers will be defective from time to time. Moreover, in the cases in which they are defective, it is easy to expect that consumers often will suffer consequential damages of one kind or another (fire or loss of data being the most obvious). At the same time, because of the cost and complexity of the average transaction, the cost in lost customers of adding an additional screen to obtain robust consent seems slight. Thus, it is no surprise that Dell has a robust contracting interface, in which a customer signals affirmative assent by clicking to agree to a contract that includes a disclaimer of implied warranties, a damage cap, a limitation on consequential damages, a choice-of law clause, arbitration clause, and waiver of class actions.

Amazon lies at the other end of the spectrum. It is difficult to imagine how Amazon might have exposure to costly consumer litigation. At least with respect to its 
core business of selling books and music, ${ }^{57}$ its products are unlikely to cause serious consequential damages. Those products are unlikely to fail to conform to any warranty that might accompany them unless the products are damaged, and Amazon (like many bookstores) has a lenient returns policy that makes serious disputes unlikely. ${ }^{58}$ In sum, Amazon has relatively little to gain from a contract. To be sure, we note above that all Internet retailers have some justifiable concern about litigation arising out of the operation of their site (as opposed to the products that they sell), but that does not undermine the point that Amazon's core business generates less demand for a pro-seller contract than that of many other Internet retailers.

At the same time, Amazon - the owner of the renowned (and vilified) ${ }^{59}$ "oneclick” patent - is the retailer most devoted to streamlined purchases, and thus most likely to be harmed by extra "clicks" in its purchase interface. ${ }^{60}$ Thus, it is no surprise that Amazon’s interface does not extract robust consent; it simply states that "[b]y placing

${ }^{57}$ As of 2005, about 2/3 of Amazon's revenues ( $\$ 5.9$ billion out of $\$ 8.5$ billion) came from the sales of "media" products, as opposed to "electronics and other general merchandise." Amazon.com 2005 Annual Report, at 36.

58 The dominance of credit cards for Internet payments makes it difficult to have an onerous returns policy, given the ease with which customers can disavow claims through the credit card system. In recent years, however, some merchants have begun to scrutinize those claims more aggressively, motivated by the perception of consumer abuse. See Michael Rubinkam, Online Sellers Getting Tough; More Merchants Challenge Fraud and Charge-Backs, HOUSTON CHRONICLE, Apr. 17, 2006 (discussing returns policy of Ice.com, I-500 Retailer \# 193).

59 See Martin Campbell-Kelly \& Patrick Valduriez, A Technical Critique of Fifty Software Patents (January 2005 draft) (discussing and rejecting criticisms of the one-click patent).

${ }^{60}$ See, e.g., Keith Regan, Amazon Dips Toe into Online Grocery Business, E-COMMERCE TIMES, June 15, 2006 (discussing importance of "ultra-convenient shopping experience" to Amazon's effort to enter the online grocery business); Lou Hirsh \& Jennifer LeClaire, Kings of Repeat E-Business, E-COMMERCE TIMES, Aug. 26, 2002 (discussing Amazon's early and effective use of personalization technology at its site). For academic discussion on the importance of short purchase paths at Web sites, see Montgomery et al., supra note 12. 
your order, you agree to Amazon.com's privacy notice and conditions of use," which are available in small-type links at the bottom of the page (links that are not ordinarily visible at the same time as the quoted text). At the same time, the conditions of use include a number of pro-seller clauses: a disclaimer of implied warranties, limitation on consequential damages, choice of law, choice of forum, and arbitration clauses, and a waiver of class actions.

Another complicating factor is the development of interfaces over time, which suggests that the design of retailer contracts and interfaces is subject to a significant learning curve. Dell's history provides the clearest evidence, because four published judicial opinions addressing the presence of assent in an online sale with Dell ${ }^{61}$ illuminate the development of its interface from 2004 through early 2006. Although it is difficult to clearly determine where Dell was on the consent continuum at any given time without screen shots (which we only have as of only the first quarter of 2006), the cases suggests that Dell went through the following progression: beginning in 2004, Dell had a pure browse-wrap; ${ }^{62}$ sometime in 2005, Dell switched to browse-wrap with a statement that a purchase is subject to terms and conditions (and possibly a link next to that statement) ${ }^{63}$ and, in the first quarter of 2006, which we have screen shots of, to a

${ }^{61}$ Provencher v. Dell, Inc, 409 F. Supp. 2d 1196 (S.D. Ca. 2006); Rogers v. Dell Computer Corp., 127 P.3d 560 (Okla. 2005); Hubbert v. Dell Corp., 835 N.E.2d 113 (Ill. App. Ct. 2005); Defontes v. Dell Computers Corp., 2004 R.I. Super. LEXIS 32 (2004). There is a fifth case that deals with customer's assent, but the court only discusses the shrink-wrapped contract in reasoning that the consumer had assented to the arbitration provision. Stenzel v. Dell, Inc., 870 A.2d 133, 139-40 (Me. 2005).

62 Defontes, 2004 R.I. Super. LEXIS 32 at $* 4$ (describing Dell's websites as allowing users to view the terms of use "as a hyperlink on the bottom of Dell's website").

${ }^{63}$ Hubbert, 835 N.E.2d at 117 (stating that the following statement was present on three of Dell's order pages: “'All sales are subject to Dell's Terms and Conditions of Sale.”). It is hard to determine exactly what confronted the plaintiff in Provencher, as the court simply stated: “The Agreement was available for Mr. Provencher's review on Dell's website before, while, and 
statement with a radio button that requires affirmatively clicking to proceed and a link to the terms and conditions. ${ }^{64}$ The first two steps in Dell's progression are discussed in reported opinions; ${ }^{65}$ there is not yet a case discussing Dell’s current online purchasing process, which includes the robust click-through interface discussed above.

Not surprisingly in light of the discussion of contracting rules in Part II, the cases discussing Dell's earlier interfaces were not uniformly favorable. Thus, in its 2004 decision in Defontes v. Dell, the Superior Court of Rhode Island held that the arbitration clause in Dell's terms and conditions did not bind the plaintiff, reasoning that the browsewrap "was not sufficient to put Plaintiff's on notice of the terms and conditions of the sale of the computer." ${ }^{66}$ One year later, the Illinois Court of Appeals in Hubbert v. Dell Corp. faced a newly remodeled Dell website, on which the terms were available through a hyperlink at the bottom of the page and three order pages stated that "All sales are subject to Dell's Terms and Conditions of Sale.”67 The court held that this statement was enough to put a reasonable person on notice of the terms and thus make them binding against customers. ${ }^{68}$

after he ordered the computer . . .” 409 F. Supp. 2d at 1199. This is even more difficult in Rogers where the court professed itself unable to determine "whether the plaintiffs were required to consent to the "Terms and Conditions of Sale."” 127 P.3d at 563.

${ }^{64}$ Dell, I500 Dataset.

${ }^{65}$ Defontes discusses Dell's site as a browse-wrap agreement and uses a reasonable notice standard. 2004 R.I. Super. LEXIS 32 at *17. Both Rogers and Hubbert seem to discuss Dell's site as browse-wrap with a statement referring to the Terms and Conditions; however, each case uses different reasoning. Rogers, 127 P.3d at 566-68 (reasoning based on time of formation); Hubbert, 835 N.E.2d at 129 (reasoning based on notice). Provencher gives little indication of the status of Dell's website and assumes the validity of the online contract. 409 F. Supp. 2d at 1199.

${ }^{66} 2004$ R.I. Super. LEXIS 32 at *17.

67835 N.E.2d at $121-22$.

${ }^{68} I d$. The ambiguity of the term "browse-wrap" is evident from the discussion in the ALI Principles, which regard Hubbert as an example of browse-wrap despite the relatively plain notice and accessibility of the terms on the order pages. See ALI PRINCIPLES, supra note 10, $\S$ 
Surely the weakest reasoning employed in this line of cases appears is Rogers $v$. Dell. ${ }^{69}$ In Rogers, the court addresses the same issue as the above two cases, but instead of resolving the question of enforceability based on the objective and undisputed facts about the interface, the Oklahoma Supreme Court saw this issue as a battle-of-the-forms issue to be determined by the facts of each case. ${ }^{70}$ Although it had as much evidence as the other two courts that decided the issue, the court in Rogers remanded the case for further fact finding to determine when exactly an offer and acceptance occurred to determine what terms were included in the initial contract and to determine if those online terms were included or offered as additional terms. ${ }^{71}$ Determining why a business does something is difficult, but the unpredictability of that response to its interface certainly gave Dell a notable incentive to adopt the more robust click-wrap interface that it now uses.

Collectively, the anecdotal information above gives some reason to despair in trying to develop a conceptual model of the contracting decision that can be verified with quantitative data. The line of cases involving Dell can cut in different ways. The discussion above reports the litigation as illustrating why it is important for Dell to have the interface that it now has. But it also can be read more critically: shouldn't it have been obvious to Dell by the turn of the century that it needed a robust contracting interface to protect itself from claims by its customers?

2.01 comment b. In any event, for purposes of the coding in our dataset this would not have been treated as pure browsewrap. Moreover, as we discuss in the text, Dell's subsequent experience in litigation apparently has convinced it that the decision in Hubbert is not sufficiently reliable to justify retaining the interface at issue in that case.

69127 P.3d 560 (Okla. 2005).

${ }^{70} \mathrm{Id}$.

${ }^{71} I d$. 
Given those problems, we approach the statistical analysis with an open mind about the possibility of multiple explanations for the contracting practices we have found. Conceptually, as Figure 1 illustrates, we examine the interactions among three distinct sets of variables: business variables, the terms of contracts, and the form of assent. The arrows in Figure 1 indicate the three most likely causal relations among those groups of variables: that the business variables relate to the use of pro-seller terms, that the business variables relate to the level of assent, and that the pro-seller terms relate to the level of assent. It is possible that causation runs in the reverse direction: that the robustness of assent or the existence of terms relate to the business variables. For example, some exogenous reason might drive businesses to choose an effective interface or a pro-seller contract and that choice might lead to success of the business or its site (measured by sales, visitors, product scope, or the like). In our view, however, the low levels of robust contracting described in Part III make that "contract-driven” hypothesis unlikely. Accordingly, we have not analyzed that possibility in detail and do not discuss it in the sections that follow. The three sections that follow discuss our preliminary analysis of the relation between the business variables and the level of assent, between the use of pro-seller terms and the level of assent, and finally between business variables and the use of pro-seller terms. 
Figure 1: Potential Relationships Among Variables

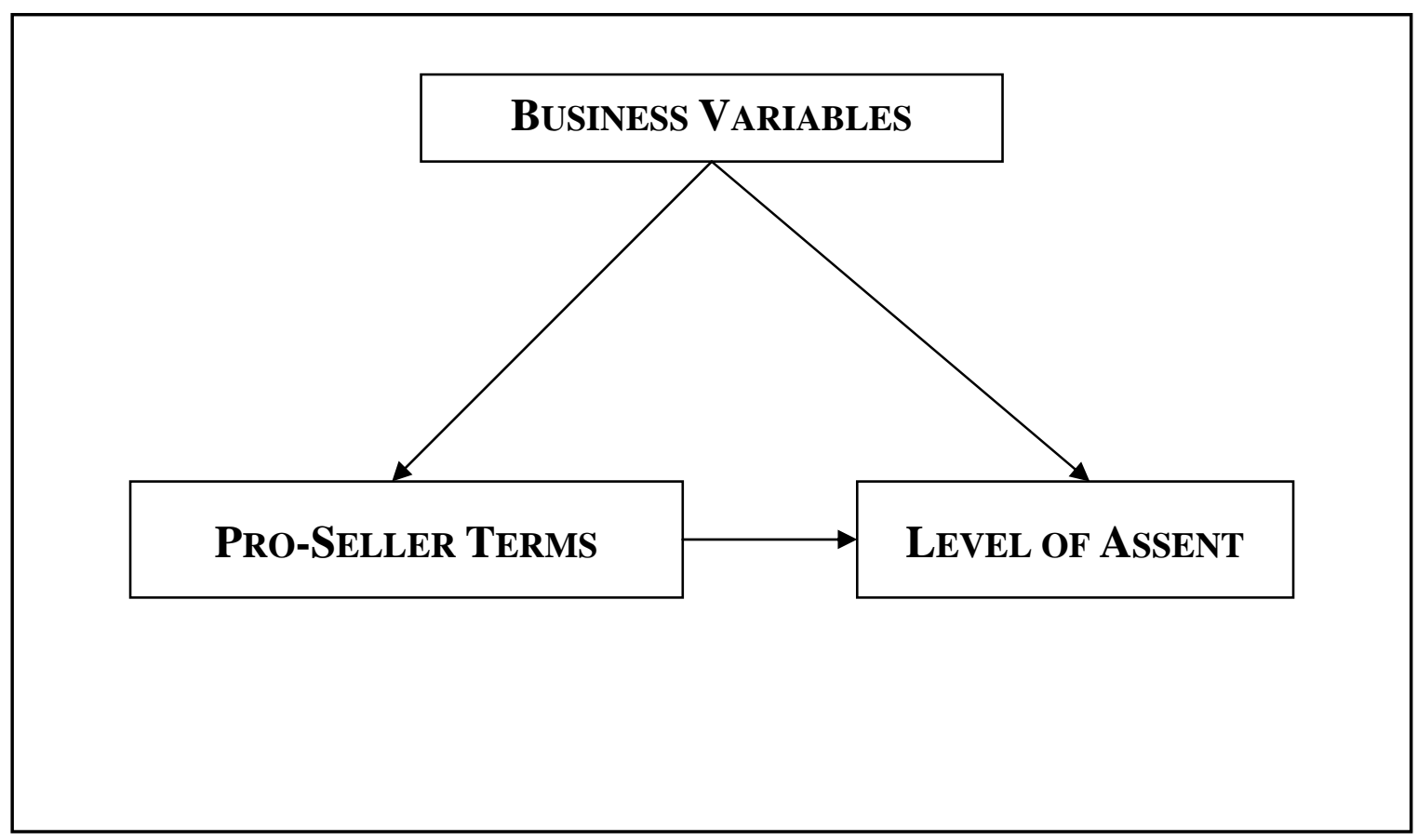

1. Business Variables and Assent.-We start with our primary working hypothesis: that the best place to look for an explanation of the contracting interface is in data about the business of the firm designing the interface. Our data permit us to explore several possibilities about the relation between the business model of the firm and its contracting interface. To take the most general examples from the discussion above, if we assume that the value of assent correlates with the price of the good sold, then we should expect firms to seek robust assent more often when they sell expensive objects. If this is true, the average ticket at the site is a good proxy. Similarly, the discussion of Dell's litigation history suggests that it is technologically difficult to design a well-crafted interface that extracts consent without unduly distracting customers. ${ }^{72}$ If so, the extent of

${ }^{72}$ The science (or art, depending on your perspective) of designing retailer Web site interfaces is a rapidly developing one. To get a sense for the issues designers face, see, for 
a firm's investment in its e-commerce business might relate to the robustness of assent. Thus, firms for whom the site is a relatively small adjunct of a larger retail business (Nordstrom.com, for example) might be less likely than firms like Dell to have devoted the resources to design a high-quality interface. To consider that possibility, we constructed a Web Scope Index that combines the total sales, number of monthly visits to the site, and the number of monthly unique visitors to the site. A third possibility, considerably less general, is that the characteristics of particular product lines and distribution channels might affect the contracting interface.

We started with some simple tabulations of the level of assent for each of the fourteen merchandising markets. As Table 7 illustrates, the percentage of sites obtaining robust assent in particular markets differed widely from the $5.6 \%$ in the overall dataset. The bold-face type indicates the two markets where the variation was significant at the 5\% level: computers/electronics and food/drug both had unusually high levels of assent. The italics indicate the three markets with variations significant at the $10 \%$ level: Books/CDs/DVDs and Toys/Hobbies had an unusually high level, while apparel/accessories had an unusually low level. ${ }^{73}$

example, Rachelle Crum, ATG's Cliff Conneighton: E-Tailers Can't Wing It Anymore, ECOMMERCE TIMES, Feb. 21, 2007 (interview with interface-design consultant who advises retailers such as Best Buy, Target, Nike, Neiman Marcus, and OfficeMax).

73 We tested the variations using a two-sample test of proportion and determine significance based on the $\mathrm{z}$ statistic from that test. 
TABLE 7: MERChANDISING MARKETS AND AssENT

\begin{tabular}{||c|c|c|c||}
\hline MARKET & $\begin{array}{c}\text { VOLUME } \\
(\mathrm{M} \$)\end{array}$ & $\mathrm{N}$ & \% W/ ASSENT \\
\hline Mass Merchant/Dep't Store & 18,300 & 27 & 3.7 \\
\hline Computers/Electronics & $\mathbf{1 7 , 7 0 0}$ & $\mathbf{5 4}$ & $\mathbf{1 3 . 0}$ \\
\hline Office Supplies & 10,300 & 11 & 0 \\
\hline Apparel/Accessories & 7,060 & 109 & 1.8 \\
\hline Books/CDs/DVDs & 2,500 & 29 & 13.8 \\
\hline Housewares/Furnishings & 2,410 & 55 & 1.8 \\
\hline Specialty/Non-Apparel & 2,330 & 60 & 1.7 \\
\hline Food/Drug & $\mathbf{1 , 8 7 9}$ & $\mathbf{2 6}$ & $\mathbf{1 5 . 4}$ \\
\hline Health/Beauty & 1,750 & 17 & 5.9 \\
\hline Sporting Goods & 1,340 & 39 & 2.6 \\
\hline Flowers/Gifts & 1,200 & 18 & 5.6 \\
\hline Hardware/Home Impr. & 851 & 22 & 9.1 \\
\hline Toys/Hobbies & 741 & 19 & 15.8 \\
\hline Jewelry & 615 & 14 & $\mathbf{5 . 6}$ \\
\hline TOTAL & $\mathbf{6 8 , 9 0 0}$ & $\mathbf{5 0 0}$ & \\
\hline \multicolumn{1}{|c|}{} & \multicolumn{2}{|c||}{} \\
\hline
\end{tabular}

Some of those results are easy to understand. For example, the discussion at the beginning of this part supports the idea that electronics retailers are leaders in obtaining assent. Also, with respect to food and drug retailers, all of the firms seeking robust assent come within the subcategory of firms specializing in home delivery of groceries (PeaPod, FreshDirect, Safeway, and Albertson's). Because customers at those retailers are likely to return to the site frequently and spend a great deal of time there, we can speculate that the additional marginal cost of extracting robust assent is relatively slight. Conversely, most of the firms that sell books, toys, and apparel are likely to be adjuncts of brick-andmortar firms that customarily have sold products without obtaining formal contracts from their customers. If the firms start from a baseline in which formal contracting has not been necessary, they may see less reason to require formal contracts than virtual firms that start without such experience. To illustrate that point, consider Table 9, which shows 
that assent is much more common in wholly virtual firms than it is in firms that have adjunct retail operations.

TABle 8 (Merchandising Channels AND AssenT)

\begin{tabular}{||c|c|c|c||}
\hline CATEGORY & VOLUME (B\$) & N & \% W/ ASSENT \\
\hline $\begin{array}{c}\text { Brick and } \\
\text { Mortar }\end{array}$ & 48.2 & 275 & 2.9 \\
\hline Virtual & 20.8 & 225 & 8.9 \\
\hline TOTAL & 68.9 & 400 & 5.6 \\
\hline
\end{tabular}

The stark difference between virtual and non-virtual retailers provides some support for the "learning-curve" explanation discussed above. The idea is that retailers that start with a Web site are likely to investigate the value of a robust interface as a stand-alone question, while retailers that add a Web site as a new distribution channel for an existing retail operation are more likely to view the site as an adjunct to their existing operations. Those firms might see no reason why they should seek more robust assent to contracts online than they typically do in the brick-and-mortar environment. If so, those firms might systematically have less robust interfaces than virtual firms.

The obvious question, of course, is whether the relations we identified for those particular sectors relate to the sectors themselves - something special about the retailing of computers or food or toys, for example - or rather to quantifiable aspects of the retailer's operations (like average ticket, Web Scope Index, or other variables). To test that question, we used multivariate logistic regressions to analyze a model that tested the relation between robust assent and variables related to the firm's average ticket, Web sophistication (measured by the Web Scope Index), together with a number of other variables as controls (dummies for the various merchandise markets, merchandising channels, market power, and the like). 
As Tables A1 and A2 (in the Appendix) illustrates, those regressions support the hypothesis that average ticket is an important indicator of a firm's contracting interface. In each of several models, average ticket was significant at least at the $1 \%$ level. The odds ratios also are quite high (in the range of 3), suggesting that the relation also is economically significant.

The regressions provided less support for our other hypotheses. For example, once average ticket is included in the model, we found no significance for any of the product-market dummies (electronics, food/drugs, etc.) or the merchandising channel variable (virtual versus brick-and-mortar). Similarly, we found relatively little support for the learning-curve hypothesis discussed above. Specifically, our "Web Scope Index," which combines total sales, monthly visitors, and monthly unique visitors into a single variable, borders on significance in a few of the specifications but generally is not significantly related to the level of assent obtained by the site's interface. Finally, although it was not a focus of our research, we note that our controls related to market power were rarely significant, suggesting that neither the market power of the seller nor the competitive structure of the particular sector are important predictors of the type of contracting interface.

2. Clauses and Assent.-The analysis in the preceding section is straightforward enough by itself, but it does not consider the possibility that the presence of pro-seller clauses might motivate the firms to design robust interfaces for obtaining assent. Accordingly, we next investigated the relation between the clauses and the level of assent. As we would have expected, it appears that there is a significant relation between most of the nine selected clauses and the level of assent. Four of the clauses are related 
to the existence of robust assent at the $1 \%$ level (damage caps, arbitration, waiver of class action, and contractual statute of limitation) and three more at the 5\% (disclaimer of implied warranty) and 10\% (consequential damages disclaimer, choice of forum) levels. Choice of law clauses approach $10 \%$ significance; only jury trial waivers seem wholly unrelated. Table A3 in the Statistical Appendix summarizes that analysis. ${ }^{74}$

That relation is reassuring, because it suggests that rational factors are driving the contracting practices of firms, but it is still the case that the great majority of each type of pro-seller clause appears in contracts that are not presented in an interface that would reliably make the contracts enforceable against customers. Accordingly, we caution, it would be far too simple to say that firms adopt robust interfaces because their business needs have driven them to include pro-seller clauses in their contracts.

Not surprisingly, there is considerable overlap among the firms that have the selected clauses. 234 of the firms have none of the clauses. Integrating that data point with Table 6 above suggests that about $90 \%$ of the firms that have any pro-seller terms in their documents have a disclaimer of implied warranties (245/266) and a limitation of consequential damages (243/266). Figure 3 illustrates the number of clauses among the 266 firms that have any pro-seller clauses. As that table suggests, about half of those firms have either four or five of the nine clauses; only three have more than seven of them.

${ }^{74}$ Although we are skeptical about the value to be gained by simply counting onerous clauses, we did analyze the relation between the number of onerous clauses in a firm's contract and the level of assent. There is a correlation coefficient of about $13 \%$, significant at the $1 \%$ level. Given the discussion in Part II of reasons why a firm might include those clauses and yet not obtain assent to its terms, it is not surprising that the correlation is so low. 
Figure 3: Overlap of Pro-seller Clauses

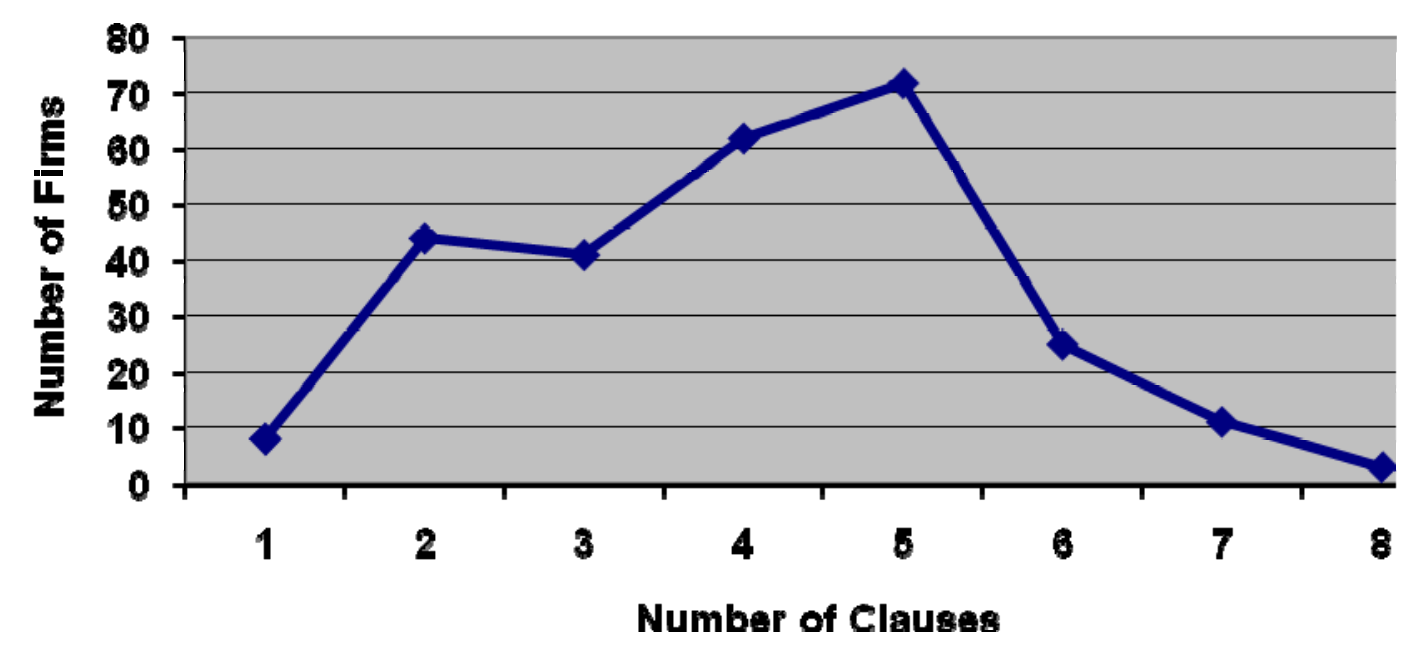

That raises the question whether any particular clause is so important that it might have an effect on the interface that dominates the effect of the other clauses. To investigate that question, we examined models attempting to explain the robustness of assent by the presence of the clauses. Although we found scattered results suggesting a positive relation between assent and arbitration and a negative relation between assent and choice-of-forum clauses, the most robust and stable relations are for damage caps and contractual statutes of limitation. The inconsistent nature of those results, together with the discussion above leads us to discount the economic significance of that analysis. At bottom, the appearance of the overwhelming majority of pro-seller clauses in interfaces that do not obtain robust assent suggests that the presence of those clauses is not one of the leading causes of robust contracting interfaces.

3. Business Variables and Pro-seller Terms.-The final leg of our triangle is the relation between the business variables and pro-seller terms. The analysis in the preceding section treats pro-seller terms as a separate condition that might determine the level of assent even apart from the business variables discussed in the preceding section. 
Another possibility is a mediation hypothesis: that the pro-seller terms "mediate" the effect of the business variables: the business variables create the need for some pro-seller term (such as an arbitration clause or disclaimer of consequential damages), which in turn motivates the firm to design a robust contracting interface. The analysis we articulate in Part II cuts against the mediation hypothesis, because it suggests that the need for a robust contracting interface derives from factors distinct from the need for pro-seller clauses: if customers often will accede to the effect of pro-seller clauses even when they have not been made legally binding then the firm's need for a binding interface may be caused by factors separate from those that lead it to include pro-seller terms.

To investigate that problem, our last set of analyses considered the extent to which the business variables could predict use of any of the selected clauses. Based on the analysis in the preceding section, we focused on four clauses. We started with the two clauses most closely associated with assent (damage caps and contractual statutes of limitation), but we also considered consequential damages disclaimers and arbitration clauses, because of the controversial nature of those clauses. ${ }^{75}$

As summarized in Table A4, those analyses did not provide strong support for the mediation hypothesis. Although we found scattered results of significance for different clauses, we did not find the kinds of clear relationships reported in the early sections. A few generalizations seem appropriate. First, it seems clear that the business variables that are important predictors of the pro-seller clauses differ from clause to clause and for the

${ }^{75}$ See, e.g., Shante Razor v. Hyundai Motor America, 854 N.E.2d 607 (Ill. 2006) (holding disclaimer of consequential damages unconscionable); Discover Bank v. Boehr, 113 P.3d 1100 (Cal. 2005) (holding arbitration clause unconscionable); Jean R. Sternlight, Creeping Mandatory Arbitration: Is It Just?, 57 STAN. L. REV. 1631 (2005) (analyzing problems in the application of arbitration clauses). 
most part are a different set of variables than those that are related to the robust interfaces. For example, industry concentration (measured by HHI) was closely related to arbitration clauses, log of total SKUs was related to contractual statute of limitations clauses and arbitration clauses, and the Web Scope Index was related to arbitration clauses and consequential damages disclaimers. It also is clear that the business variables related to the clauses differ substantially from clause to clause. Thus, for example, the Web Scope Index is the most important variable for consequential damages, log of total SKUs is marginally related to damage caps and contractual statute of limitations, and log of average ticket, Web scope index, log of total SKUs, and HHI all are related to arbitration clauses. In general, it is apparent that the data that we have collected do not include the best variables for understanding the selection of the clauses that appear in the agreements. Thus, further qualitative research in the form of interviews, surveys, or case studies seems appropriate to provide a more complete understanding of this problem.

\section{Implications and Conclusion}

The central purpose of this Article is to dispose of some obvious misconceptions about Internet retailing. This is a burgeoning area of commerce that promises to be the most rapidly growing type of retail distribution for years to come. Yet despite the ready availability of standardized information about contracts, far too little is understood. First, for the great majority of Internet retailers, the ease of the shopping experience is more important than concerns about possible future liability. Thus, few retailers - only about $6 \%$ in our population - use contracting interfaces sufficiently robust to make it reasonable to expect that their contracts are enforceable against their customers. Second, even more surprisingly, the contracts found on those sites contain the standard boilerplate 
provisions - arbitration, disclaimers of consequential damages, and the like - much less frequently than would be expected. No such clause appears in the contracts for more than half of the retailers that we studied. We attribute the appearance of the clauses in almost half of the contracts to the conflict between two motivations: the desire to have terms that appear to be benign and the desire to have terms (albeit not in a binding form) to which consumers will accede in the event of a dispute.

More broadly, we hope to contribute to an understanding of the relation between formal and informal modes of contract enforcement. In our view, the data we present here suggest that businesses often can succeed in altering the practical terms of their relations with customers without obtaining enforceable contracts. The apparent use of unenforceable terms to guide customer behavior provides a provocative addition to the debate about whether assent should be the focus of doctrinal rules on contract formation. Among other things, it suggests that doctrinal rules that make pro-seller terms unenforceable will have considerably less impact in the real interactions of customers and merchants than scholars have surmised. This finding is particularly striking because of the remote interactions of the parties. Although many of the customers are repeat customers, there is by definition almost no opportunity for the kind of personal interaction that characterizes relational contracting as it commonly is understood. 

Statistical APPENDiX

TABLE A1: Logistic Regressions on Business VARIABLES AND ForCED AsSENT

\begin{tabular}{|c|c|c|c|c|}
\hline & $\begin{array}{c}\text { MODEL } \\
1\end{array}$ & $\begin{array}{l}\text { MODEL } \\
2\end{array}$ & $\begin{array}{c}\text { MODEL } \\
3\end{array}$ & $\begin{array}{c}\text { MODEL } \\
4\end{array}$ \\
\hline $\begin{array}{l}\text { Log Average } \\
\text { Ticket }\end{array}$ & $\begin{array}{c}3.36 \\
(1.12) \\
3.62 * * *\end{array}$ & $\begin{array}{c}4.52 \\
(2.01) \\
3.38 * * *\end{array}$ & $\begin{array}{c}2.53 \\
(.496) \\
4.75^{* * *}\end{array}$ & $\begin{array}{c}2.90 \\
(.668) \\
4.61 * * *\end{array}$ \\
\hline $\begin{array}{l}\text { Web Scope } \\
\text { Index }\end{array}$ & $\begin{array}{c}1.07 \\
(.177) \\
0.41\end{array}$ & $\begin{array}{c}.990 \\
(.184) \\
-0.05\end{array}$ & $\begin{array}{c}1.01 \\
(.166) \\
0.03\end{array}$ & $\begin{array}{c}.937 \\
(.166) \\
-0.37\end{array}$ \\
\hline $\begin{array}{c}\text { Log Total SKUs } \\
\text { on Web }\end{array}$ & -- & $\begin{array}{c}1.24 \\
(.185) \\
1.46\end{array}$ & -- & $\begin{array}{c}1.19 \\
(.148) \\
1.43\end{array}$ \\
\hline HHI & $\begin{array}{c}1.0007 \\
(.0004) \\
1.81 \#\end{array}$ & $\begin{array}{c}1.0007 \\
(.0005) \\
1.34\end{array}$ & $\begin{array}{c}1.0004 \\
(.0003) \\
1.38\end{array}$ & $\begin{array}{c}1.0002 \\
(.0003) \\
0.60\end{array}$ \\
\hline $\begin{array}{l}\text { MERCHANDISING } \\
\text { DUMMIES } \\
\end{array}$ & YES & YES & No & No \\
\hline $\mathrm{N}$ & 451 & 271 & 492 & 310 \\
\hline Pseudo R2 & .211 & .235 & .098 & .131 \\
\hline
\end{tabular}

The Table reports the odds ratio with the robust standard error in parentheses, followed by the $\mathrm{z}$ statistic. $\#--10 \%,{ }^{*}--5 \%,{ }^{* *}--1 \%, * * *--.1 \%$.

We also ran a similar set of models, using ordered logit and a variable that recognizes the eight different types of forced assent as a categorical variable with eight ordered categories. The results are set out below in Table A2. The table reports the coefficient, with the robust standard error in parentheses, followed by the z-score. 
TABLE A2: ORDERED LOGIT REgRESSIONS ON BUSINESS VARIABLES AND FORCED ASSENT

\begin{tabular}{||c|c|c|c|c||}
\hline & MODEL & MODEL & MODEL & MODEL \\
& 1 & 2 & 3 & 4 \\
\hline Log Average & $\mathbf{. 8 2 2 7}$ & $\mathbf{1 . 1 6}$ & $\mathbf{. 7 1 9}$ & $\mathbf{. 8 8 7}$ \\
Ticket & $\mathbf{( . 1 6 4 )}$ & $\mathbf{( . 2 2 9 )}$ & $\mathbf{( . 1 5 7 )}$ & $\mathbf{( . 1 8 5 )}$ \\
& $\mathbf{5 . 0 1 * * *}$ & $\mathbf{5 . 0 4 * * *}$ & $\mathbf{4 . 5 8 * * *}$ & $\mathbf{4 . 7 9 * * *}$ \\
\hline Web Scope & .189 & .165 & .191 & .127 \\
Index & $(.131)$ & $\mathbf{( . 1 6 0 )}$ & $(.099)$ & $(.104)$ \\
& 1.44 & 1.03 & $1.92 \#$ & 1.22 \\
\hline Log Total SKUs & & .113 & & .131 \\
on Web & -- & .109 & -- & $(.095)$ \\
& & 1.04 & & 1.39 \\
\hline HHI & .0003 & $\mathbf{. 0 0 1 0}$ & .0005 & .0004 \\
& $(.0003)$ & $\mathbf{( . 0 0 0 5 )}$ & $(.0002)$ & $(.0002)$ \\
& 0.80 & $\mathbf{2 . 1 7 *}$ & 3.21 & $1.65 \#$ \\
\hline MERCHANDISING & YES & YES & No & No \\
DuMMIES & & & & \\
\hline N & 492 & 310 & 492 & 310 \\
\hline Pseudo R2 & .119 & .161 & .060 & .079 \\
\hline \hline \multicolumn{1}{|c|}{} & & & & \\
\hline
\end{tabular}


TABle A3: Pro-Seller Clauses AND ForCed Assent

\begin{tabular}{|c|c|c|c|c|}
\hline CLAUSE & FREQUENCY & CHI2 & LOGISTIC & OLOGIT \\
\hline $\begin{array}{c}\text { Disclaimer of } \\
\text { implied } \\
\text { warranty }\end{array}$ & 245 & 0.040 & $\begin{array}{c}2.91(2.54) \\
1.22\end{array}$ & $\begin{array}{c}.764(.656) \\
1.16\end{array}$ \\
\hline $\begin{array}{c}\text { Limitation of } \\
\text { damage type }\end{array}$ & 243 & 0.087 & $\begin{array}{c}.430(.380) \\
-0.96\end{array}$ & $\begin{array}{c}-.054(.703) \\
-0.08\end{array}$ \\
\hline Damage caps & 108 & 0.005 & $\begin{array}{c}2.68(1.40) \\
1.89 \#\end{array}$ & $\begin{array}{c}\mathbf{. 8 3 9}(.356) \\
\mathbf{2 . 3 5 *}\end{array}$ \\
\hline Choice of law & 387 & 0.137 & $\begin{array}{c}.677(.489) \\
-0.54\end{array}$ & $\begin{array}{c}-.041(.489) \\
-0.08\end{array}$ \\
\hline $\begin{array}{c}\text { Choice of } \\
\text { forum }\end{array}$ & 159 & 0.087 & $\begin{array}{c}.832(.575) \\
-0.27\end{array}$ & $\begin{array}{c}-.739(.429) \\
-1.72 \#\end{array}$ \\
\hline $\begin{array}{c}\text { Arbitration } \\
\text { Waiver of class } \\
\text { action }\end{array}$ & 44 & 0.002 & $\begin{array}{c}2.43(2.48) \\
0.87\end{array}$ & $\begin{array}{c}\mathbf{1 . 3 9}(.636) \\
\mathbf{2 . 1 8} *\end{array}$ \\
\hline $\begin{array}{c}\text { Statute of } \\
\text { limitations }\end{array}$ & 28 & 0.001 & $\begin{array}{c}1.86(2.01) \\
0.58\end{array}$ & $\begin{array}{c}.074(.691) \\
0.11\end{array}$ \\
\hline $\begin{array}{c}\text { Jury trial } \\
\text { waiver }\end{array}$ & \multirow{2}{*}{6} & 0.004 & $2.94(1.88)$ & $\begin{array}{c}.889(.532) \\
1.69 \#\end{array}$ \\
\hline
\end{tabular}

Jury trial waiver is dropped from the logistic and ologit regressions because of the small number of clauses and lack of relation in the chi2 test. Although we do not report them here, we analyzed models parallel to columns 3 and 4 including average ticket as a control. Those runs displayed similar relations, except that arbitration lost its significance. 
TABle A4: Business VARIABles AND Pro-Seller TeRMS

\begin{tabular}{|c|c|c|c|c|c|c|c|c|}
\hline & \begin{tabular}{|c} 
DAMAGE \\
CAPS 1
\end{tabular} & $\begin{array}{l}\text { DAMAGE } \\
\text { CAPS } 2\end{array}$ & $\begin{array}{c}\text { KSOL } \\
1\end{array}$ & $\begin{array}{c}\text { KSOL } \\
2 \\
\end{array}$ & "ARBIT. 1 & $\begin{array}{l}\text { ARBIT. } \\
2\end{array}$ & $\begin{array}{c}\text { CONS'Q } \\
1 \\
\end{array}$ & \begin{tabular}{|c} 
CONS'Q. \\
2 \\
\end{tabular} \\
\hline $\begin{array}{l}\text { Log Average } \\
\text { Ticket }\end{array}$ & $\begin{array}{c}.834(.146) \\
-1.04\end{array}$ & $\begin{array}{c}1.144 \\
(.0799) \\
-0.86\end{array}$ & $\begin{array}{c}1.056 \\
(.315) \\
0.18 \\
\end{array}$ & $\begin{array}{l}2.090 \\
(.667) \\
2.31 * \\
\end{array}$ & $\begin{array}{c}1.86 \\
(.443) \\
2.61 * *\end{array}$ & $\begin{array}{c}1.88 \\
(.501) \\
2.35 * \\
\end{array}$ & $\begin{array}{l}.8344 \\
(.116) \\
-1.30 \\
\end{array}$ & $\begin{array}{c}.911 \\
(.162) \\
-0.52 \\
\end{array}$ \\
\hline $\begin{array}{l}\text { Web Scope } \\
\text { Index }\end{array}$ & $\begin{array}{c}1.222 \\
(.294) \\
0.84\end{array}$ & $\begin{array}{c}1.08 \\
(.206) \\
0.40\end{array}$ & $\begin{array}{c}1.07 \\
(.153) \\
0.49\end{array}$ & $\begin{array}{c}1.33 \\
(.238) \\
1.59\end{array}$ & $\begin{array}{l}1.696 \\
(.301) \\
2.98 * *\end{array}$ & $\begin{array}{l}1.74 \\
(.401) \\
2.39 *\end{array}$ & $\begin{array}{c}7.93 \\
(4.71) \\
3.49 * * *\end{array}$ & $\begin{array}{c}36.6 \\
(37.2) \\
3.54 * * *\end{array}$ \\
\hline Log Total SKUs & -- & $\begin{array}{l}1.144 \\
(.080) \\
1.93 \#\end{array}$ & -- & $\begin{array}{l}1.366 \\
(.164) \\
2.60 * *\end{array}$ & -- & $\begin{array}{c}1.29 \\
(.1235) \\
2.64 * *\end{array}$ & -- & $\begin{array}{c}1.09 \\
(.067) \\
1.45\end{array}$ \\
\hline HHI & $\begin{array}{c}.9995 \\
(.0003) \\
-1.33 \\
\end{array}$ & $\begin{array}{c}.9997 \\
(.0003) \\
-0.86 \\
\end{array}$ & $\begin{array}{c}.9996 \\
(.0005) \\
-0.90 \\
\end{array}$ & $\begin{array}{c}1.001 \\
(.0005) \\
1.03 \\
\end{array}$ & $\begin{array}{c}1.0004 \\
(.0002) \\
1.72 \# \\
\end{array}$ & $\begin{array}{c}1.0008 \\
(.0003) \\
2.55 * \\
\end{array}$ & $\begin{array}{c}1.0001 \\
(.0002) \\
0.41 \\
\end{array}$ & $\begin{array}{c}.9998 \\
(.0003) \\
-0.53 \\
\end{array}$ \\
\hline $\begin{array}{l}\text { MERCHANDISING } \\
\text { DUMMIES }\end{array}$ & YES & YES & YES & YES & YES & YES & YES & YES \\
\hline $\mathrm{N}$ & 492 & 310 & 478 & 187 & 426 & 260 & 492 & 310 \\
\hline Pseudo R2 & .087 & .077 & .113 & .205 & .155 & .224 & .090 & .175 \\
\hline
\end{tabular}

